\title{
EFEKTIVITAS PEMBERIAN BEBERAPA JENIS BAHAN ORGANIK TANDAN KOSONG KELAPA SAWIT DAN MIKORIZA PADA TANAMAN KARET DI TANAH CEKAMAN KEKERINGAN
}

\section{Santa Maria Lumbantoruan*, Asmarlaily Sahar, Deni Elfiati, Chadra sitohang}

Program Studi Agroekoteknologi, Fakultas Pertanian, USU, Medan 20155

*Corresponding author: mariasanta98@yahoo.com

\begin{abstract}
ABSTRAK
Penelitian ini bertujuan untuk mengetahui respon pemberian Bahan Organik TKKS dan Mikoriza terhadap pertumbuhan stum karet berpayung dua ditanah cekaman kekeringan pada kadar $60 \%$. Penelitian ini dilaksanakan di rumah kasa Fakultas Pertanian USU ( $\pm 25 \mathrm{~m} \mathrm{dpl})$ pada bulan November 2014 - Mei 2015 menggunakan Rancangan Acak Lengkap Faktorial (RAL) dengan dua faktor. Fakktor pertama yaitu dosis Bahan Organik Tandan Kosong Kelapa Sawit (TKKS) dengan 4 taraf yaitu 0 g/polybag, 300 g/polybag, 600 g/polybag, 900 g/polybag; dan faktor kedua yaitu jenis Mikoriza dengan 4 taraf yaitu tanpa mikoriza, Glomus, Acaulospora, Glomus+Acaulospora. Hasil penelitian menunjukkan bahawa aplikasi bahan organik TKKS memiliki pengaruh yang nyata terhadap tinggi tanaman dan cenderung nyata pada diameter batang. Dimana taraf terbaiknya diperoleh pada dosis $600 \mathrm{~g} / \mathrm{polybag}$. Pemberian Mikoriza tidak berpengaruh nyata namun dapat meningkatakan rata-rata tinggi tanaman dan diameter batang. Jenis mikoriza yang terbaik diperoleh pada jenis mikoriza yang digabung yaitu Glomus + Acaulospora. interaksi antara bahan organik TKKS dan Mikoriza tidak berpengaruh nyata namun dapat meningkatkan rata-rata tinggi tanaman dan diameter batang. Taraf kombinasi yang terbaik terdapat pada Bahan Organik TKKS 300 g/polybag dan Mikoriza Glomus + Acaulospora.
\end{abstract}

Kata kunci: Bahan Organik TKKS, Mikoriza, Cekaman Kekeringan, dan Karet

\section{PENDAHULUAN}

Karet merupakan salah satu komoditi perkebunan penting bagi Indonesia, baik sebagai sumber pendapatan, kesempatan kerja dan devisa, pendorong pertumbuhan ekonomi, serta pelestarian lingkungan dan sumberdaya hayati. Pada tahun 2012, areal penanaman karet di Indonesia merupakan yang terluas di dunia yaitu mencapai 3,48 juta $\mathrm{Ha}$ dengan produksi karet alam mencapai 3,04 juta ton tetapi produktivitas nasional hanya $1.080 \mathrm{Kg} / \mathrm{Ha} / \mathrm{Tahun}$ (Ditjenbun, 2013). Perbandingan luas areal menurut status perkebunan besar negara $7,11 \%$ dan perkebunan besar swasta 8,23\%. Sedangkan produksi perkebunan rakyat $78,97 \%$, perkebunan besar negara 10,08
$\%$ dan produksi besar swasta 10,95 \%. Nilai ekspor tahun 2008, sebesar 6.023.295.600. US\$ dengan volume ekspor 2.283.153,8 ton. Produksi dunia diperkirakan laju pertumbuhannya 2,5\% pertahun dan perdagangan dunia tumbuh 2,6\% (BPS, 2009).

Indonesia mempunyai potensi untuk menjadi produsen utama karet dunia walaupun saat ini masih kedua setelah Thailand, apabila berbagai permasalahan utama yang dihadapi perkebunan karet dapat diatasi dan agribisnisnya dikembangkan serta dikelola secara baik (Damanik, 2012). Pengusahaan perkebunan karet di Indonesia di kelola oleh 3 pihak yaitu perkebunan karet rakyat, perkebunan karet negara dan perkebunan karet swasta. Produksi karet 
yang dicapai belum memberikan hasil yang maksimal. Hal ini disebabkan sebagian besar pengembangan karet masih dilakukan oleh rakyat yang masih kurang menerapkan klon unggul dan juga terbatasnya lahan yang baik untuk pengembangan karet.

Pengembangan tanaman karet sebelumnya banyak dilakukan di daerah beriklim sedang sampai basah, yaitu pada daerah dengan curah hujan 2000-4000 $\mathrm{mm} /$ tahun. Pada daerah beriklim basah tanaman karet dihadapkan pada masalah persaingan penggunaan lahan, serangan penyakit gugur daun (Colletotrichum gloeosporioides) dan jamur akar putih (Rigidoporus lignosus) terutama dengan curah hujan lebih dari $3000 \mathrm{~mm} / \mathrm{th}$, umumnya sangat tinggi. Serangan kedua penyakit ini menyebabkan pertumbuhan dan produktivitas tanaman rendah, biaya produksi tinggi, dan umur ekonomi tanaman menjadi singkat, sehingga banyak pengusaha dan petani karet yang mengalami kerugian. Pendekatan yang kuratif yang selama ini digunakan untuk mengendalikan serangan penyakit gugur daun tidak efisien, karena hasilnya kurang efektif dan biayanya cukup mahal (Karyudi et al., 2004).

Menghadapi kendala penanaman karet didaerah basah dan permasalahan persaingan antar komoditas hal ini dapat diatasi dengan cara memberdayakan potensi daerah-daerah yang memiliki lahan kering. Namun daerah lahan kering mempunyai permasalahan yaitu kekeringan atau ketersediaan air merupakan faktor pembatas utama pada daerah yang memiliki lahan kering yang menyebabkan rendahnya pertumbuhan dan produktivitas tanaman. Rendahnya pertumbuhan dan produktivitas ini disebabkan oleh rendahnya luas permukaan fotosintesis. Permasalahan yang lain yang terdapat pada tanah yang mengalami kekeringan adalah ditandai dengan sifat fisik dan kimia tanah yang kurang baik, solum dangkal, curah hujan rendah, dan distribusi hujan tidak merata sehingga ketersediaan air merupakan masalah utama. Ketersediaan air merupakan faktor pembatas utama pada daerah lahan kering yang menyebabkan rendahnya pertumbuhan dan produktivitas tanaman (Fisher and Turner ,1978).

Masalah kekeringan ini dapat diatasi melalui pendekatan yaitu Dengan bantuan teknologi budidaya, diantaranya yaitu dengan pemanfaatan mikoriza dan bahan organik. Mikoriza merupakan masukan teknologi mikrobia yang mungkin dapat dikembangkan untuk mengatasi masalah kekeringan pada budidaya karet, asosiasi mikoriza dengan tanaman inang memungkinkan tanaman memperoleh air dan hara dalam kondisi lahan kering marginal. Mikoriza merupakan simbiosis antara cendawan (myces) dan perakaran (Rhiza) tumbuhan tingkat tinggi. Manifestasi dari simbiosis adalah perbaikan morfofisiologis perakaran tanaman inang. Hasil penelitian (Cristine, 2014) mikoriza jenis Acaulospora sp1 ,Acaulospora sp2 dan Glomus sp. sama baiknya dalam menginfeksi akar bibit karet.

Sistem perakaran sangat penting dalam penyerapan unsur hara karena sistem perakaran yang baik akan memperpendek jarak yang ditempuh unsur hara untuk mendekati akar tanaman. Bagi tanaman yang sistem perakarannya kurang berkembang, peran akar dapat ditingkatkan dengan adanya interaksi simbiosis dengan jamur mikoriza (Nasahi, 2010). Selain itu juga menurut Lugtenberg and Kravchenko (1999) mikroba tanah akan berkumpul di dekat perakaran tanaman (rhizosfer) yang menghasilkan eksudat akar dan serpihan tudung akar sebagai sumber makanan mikroba tanah. Bila populasi mikroba di sekitar rhizosfir didominasi oleh mikroba yang menguntungkan tanaman, maka tanaman akan memperoleh manfaat yang besar dengan hadirnya mikroba tersebut. Kehadiran mikrobia tanah dapat ditingkatkan dengan pemberian bahan organik kedalam tanaman 
Penelitian ini bertujuan untuk mengetahui pengaruh pemberian mikoriza dan bahan organik serta interaksi antara mikoriza dengan bahan organik pada pertumbuhan tanaman karet pada cekaman kekeringan, mengetahui pengaruh pemberian pada pertumbuhan karet pada cekaman kekeringan

\section{BAHAN DAN METODE}

kasa kebun percobaan Fakultas
PertanianUniversitas Sumatera Utara. Dengan ketinggian tempat $\pm 25 \mathrm{~m}$ diatas permukaan laut. Penelitian ini dilaksanakan pada bulan November 2014 - Maret 2015. Bahan tanaman menggunakan klon karet PB 260 berpayung dua ( berumur \pm 4 bulan), berasal dari balai penelitian Sei putih. Inokulan mikoriza yang digunakan diperoleh dari Universitas Sumatera Utara yaitu Glomus, Acaulospora dan Glomus + Acaulospora. Adapun bahan-bahan untuk pengamatan persentase derajat mikoriza meliputi; $\mathrm{KOH}, \mathrm{HCl}$, staining (pewarnaan), aquadest, larutan nitrogen, serta bahan-bahan lain yang mendukung penelitian.

Alat yang digunakan antara lain; ayakan, cangkul, ember, pisau, timbangan, hand sprayer, jangka sorong alat-alat ukur seperti; meteran, kertas, mistar, gelas ukur, alat-alat tulis, alat-alat laboratorium untuk pengamatan persentase infeksi derajat mikoriza seperti; kaca objek, cover glass, mikroskop, microvoltmeter, Psychrometer Wescor C-30, oven serta peralatan lain yang mendukung penelitian.

\section{Rancangan Penelitian}

Penelitian ini menggunakan rancangan acak lengkap faktorial yang terdiri dari 2 faktor yaitu:

Faktor I adalah mikoriza, dengan simbol M terdiri dari 4 taraf yaitu; M0 = Tanpa mikoriza , M1 = Glomus 100 g/polybag, M2 = Acaulospora $100 \mathrm{~g} /$ polybag, $\mathrm{M} 3=$
Glomus + Acaulospora (1:1) 100 g/polybag

Faktor II adalah pemberian bahan organik, dengan simbol B terdiri dari 4 taraf yaitu; BO = Tanpa bahan organik, BI $=$ Bahan organik $300 \mathrm{~g} / \tan (40 \mathrm{Ton} / \mathrm{Ha})$, $\mathrm{B} 2=$ Bahan organik $600 \mathrm{~g} / \mathrm{tan}(80$ Ton/Ha), B3 = Bahan organik $900 \mathrm{~g} / \mathrm{tan}$ (1200 Ton/Ha). Dengan demikian terdapat 16 kombinasi perlakuan dan setiap kombinasi perlakuan terdapat 4 ulangan sehingga diperoleh 64 Tanaman. Perlakuan cekaman kekeringan dalam kapasitas $60 \%$ (lampiran I)

Model linier untuk penelitian ini adalah sebagai berikut:

Yijk $=\mu+\tau \mathbf{i}+\beta \mathbf{j}+(\tau \boldsymbol{\beta}) \mathbf{i j}+\varepsilon \mathbf{i j k}$

Dimana :

Yijk $=$ Hasil pengamatan pada perlakuan ke-i, perlakuan pemberian bahan organik pada taraf ke $\mathrm{j}$, perlakuan inokulasi mikoriza pada taraf ke-k

$\boldsymbol{\mu}=$ Rata-rata umum nilai tengah pengamatan

$\boldsymbol{\tau} \mathbf{i}=$ Pengaruh taraf ke idari faktor mikoriza

$\boldsymbol{\beta j}=$ Pengaruh taraf ke $\mathbf{j}$ dari faktor bahan organik

$\boldsymbol{\tau} \boldsymbol{\beta}(\mathbf{i j})=$ Pengaruh interaksi pemberian mikoriza pada taraf ke-i dan bahan organik pada taraf ke $-\mathrm{j}$

вijk = Pengaruh galat pada taraf ke-i, perlakuan pemberian bahan organik pada taraf ke-j dan Perlakuan inokulasi mikoriza pada taraf ke-k

data hasil penelitian jika berpengaruh nyata dilanjutkan dengan uji beda nyata dilanjutkan dengan uji beda nyata Duncan Multiple Range Test (DMRT) pada taraf 5 \% (Matjik dan Sumertajaya, 2002; Gomez and Gomez, 2007).

\section{PELAKSANAAN PENELITIAN}

\section{Perbanyakan mikoriza}

Perbanyakan mikoriza di laksanakan di laboratorium biologi tanah 
Fakultas Pertanian Sumatera Utara dari awal September - Oktober 2014. Tanaman inang yang digunakan untuk perbanyakan mikoriza adalah tanaman jagung. Media tanah yang digunakan adalah Tanah topsoil $5 \mathrm{~kg}$ dan pasir $5 \mathrm{~kg}$ yang di sterilkan selama 2 hari dengan suhu $105^{\circ} \mathrm{C}$ yang berfungsi untuk membunuh mikroorganisme yang hidup pada media perbanyakan sehingga mengurangi kompetisi antara mikoriza dan mikroorganisme lainnya dan agar tanaman inang tidak terserang hama penyakit. Setelah sterilisasi kemudian media pasir dan tanah dicampur lalu dimasukkan kedalam polybag.

Inokulum mikoriza dimasukkan kedalam lubang tanam sebanyak $150 \mathrm{~g}$ /polybag. Masing-masing jenis mikoriza dipisahkan polybag $\mathrm{G}$ berisi inokulum yang mengandung glomus dan polybag $\mathrm{A}$ mengandung inokulum mikoriza Acaulospora dan polybag $\mathrm{A}+\mathrm{G}$ mengandung inokulum mikoriza Acaulospora dan Glomus. Kemudian jagung ditanam 2 tanaman/polybag. Tanaman jagung disiram setiap hari pada kondisi yang lembab. Tanaman dipanen pada saat berumur 2 bulan dan diamati persentase infeksi mikorizanya hingga mencapai $80 \%$. Setelah pengamatan, tanah +akar tanaman jagung dicampur dan digunakan sesuai perlakuan.

\section{Pengambilan Contoh Tanah}

Tanah yang digunakan adalah tanah ultisol yang berasal dari Gebang kecamatan Langkat. Tanah diambil secara komposit, tanah yang diambil setebal 1,5 $\mathrm{cm}$ dengan menggunakan cangkul atau sekop. Tanah dikering anginkan terlebih dahulu kemudian diayak dengan menggunakan ayakan $20 \mathrm{~mm}$. Tanah yang digunakan dianalisis yang meliputi: $\mathrm{pH}$ tanah, P-tersedia, C organik, KTK dan kadar air tanah pada kapasitas lapang pengukuran kadar air kapasitas lapang diukur dengan Metode Alricks ( lampiran I). Tanah yang sudah diayak dimasukkan kedalam polybag $17 \mathrm{~kg}$.

\section{Persiapan pembibitan dan pemberian perlakuan}

Persiapan pertama yang dilakukan adalah tanah yang sudah diayak dimasukkan kedalam polybag sebanyak 5 $\mathrm{kg}$, kemudian memasukkan mikoriza sesuai perlakuan di bawah perakaran karet, lalu bibit dimasukkan ditengah lubang tanaman, tanah di masukkan lagi sebanyak $1 \mathrm{~kg}$ setelah itu dimasukkan bahan organik sesuai perlakuan dan yang terakhir tanah diisi dan dipadatkan. Untuk bibit stum mata tidur kepadatan tanah yang baik, ditandai dengan tidak goyang dan tidak dapat dicabutnya stum yang ditanam, sedangkan bibit dalam polybag pemadatan tanah dilakukan dengan hati-hati mulai dari bagian pinggir ke arah tengah.

\section{Pemupukan}

Pemupukan berupa pemberian pupuk dasar yaitu pupuk fosfat alam sebanyak $50 \mathrm{~g} /$ polybag. Pemberian pupuk ini dilakukan pada saat seminggu setelah pindah tanam

\section{Perlakuan Cekaman Kekeringan.}

Tanah Sebelum dimasukkan ke dalam polibeg terlebih dahulu dihitung kadar airnya sehingga diperoleh berat tanah kering mutlak setara $15 \mathrm{~kg}$. Selanjutnya tanah dimasukkan kedalam polibeg berukuran $15 \mathrm{~kg}$ dengan berat tanah yang sama di setiap perlakuan. Penetapan bobot tanah kering udara (BTKU) yang akan dimasukkan dalam polibeg percobaan didasarkan atas kadar air tanah (KA) mengikuti Metode Alricks. Perhitungannya adalah BTKU $=\mathrm{BTKO}+$ (\% KA x BTKO), dimana BTKO adalah bobot tanah kering oven. Sedangkan volume air yang harus ditambahkan untuk mencapai kapasitas lapang adalah (KL KA) x BTKO, dimana KL adalah kadar air kapasitas lapang.

Kondisi stres air pada kapasitas $60 \%$ adalah kondisi stres pada tingkat terakhir, yang mana apabila kondisi tersebut diturunkan tanaman akan mati. Hal ini dibuktikan oleh penelitian 
Cristine, (2014) pada tanaman karet, kondisi stress air pada kadar $40 \%$ mengakibatkan tanaman tidak bertahan lama ( mati ). Dengan demikian BTKU untuk kondisi stress air ( $60 \% \mathrm{KL}$ ) adalah BTKU + (0.6 x (KL - KA) x BTKO). Perlakuan cekaman kekeringan dilakukan setelah menghitung kadar air tanah berdasarkan kapasitas lapang dengan metode Alrick ( lampiran I ).

Sejak waktu tanam sampai tanaman berumur 2 minggu, tanaman ditumbuhkan pada kadar air tanah $100 \%$ kapasitas lapang. Setelah tanaman berumur 2 minggu dalam polybag, maka tanaman diperlakukan dengan cekaman kekeringan dengan perlakuan $60 \%$ kapasitas lapang masing-masing sampai tanaman berumur 4 bulan. Dengan cara berat tanah + tanaman karet ditimbang dikurangi dengan berat tanah pada saat kapasitas bobot berat tanah kapasitas lapang.

\section{Perawatan Tanaman}

Tempat penelitian dibersihkan dari gulma dan tumbuhan yang menganggu disekitar lokasi penelitian dan di dalam polybag. Pembersihan dilakukan $1 \mathrm{x}$ sebulan. Tunas-tunas liar yang ada di sekitar batang tanaman diuang agar tidak meganggu pertumbuhan tanaman. Pembuangan tunas dilakukan $1 \mathrm{x}$ seminggu.

Pengendalian hama yang dilakukan pada saat penelitian adalah pengendalian secara nabati.pada saat tanaman berumur 1 bulan tanaman diserang hama trips dan dikendalikan dengan pemberian ekstrak daun tembakau. Pengendalian dilkukan sekali seminggu dan dilkukan selama 2 bulan. Sedangkan untuk pengendalian penyakit embun tepung digunakan belerang dengan menggunakan hand blower

\section{Parameter Penelitian}

Parameter yang diamati adalah:

\section{Pertambahan Tinggi Tanaman}

Diukur dari pertautan okulasi sampai titik tumbuh tertinggi. Pengukuran tinggi tanaman dilakukan pada awal penelitian dan menghitung pertambahan tinggi tanaman sekali 2 minggu hingga akhir penelitian

\section{Pertambahan Diameter Batang}

Diukur pada ketinggian $5 \mathrm{~cm}$ dari pertautan okulasi, pertambahan diameter batang diukur dengan menggunakan jangka sorong, pengukuran dilakukan setiap sekali 2 minggu hingga akhir penelitian.

\section{HASIL DAN PEMBAHASAN}

\section{Pertambahan Tinggi Tanaman $(\mathrm{cm})$}

Tabel 1. Jumlah Rata-Rata Pertambahan Tinggi Bibit Karet Pada 23 Mst Pada Cekaman Kekeringan

\begin{tabular}{|c|c|c|c|c|c|}
\hline \multirow{2}{*}{ MIKORIZA } & \multicolumn{5}{|c|}{ BAHAN ORGANIK } \\
\hline & B0 & $\mathrm{B} 1$ & B2 & B3 & RATA-RATA \\
\hline $\mathrm{MO}$ & 13,82 & 17,05 & 45,2 & 36,95 & 28,256 \\
\hline M1 & 22,87 & 30,67 & 18,97 & 30,5 & 25,756 \\
\hline M2 & 5,2 & 18,5 & 42 & 42,75 & 27,113 \\
\hline M3 & 18,87 & 42,27 & 33,95 & 35,87 & 32,744 \\
\hline TOTAL & $15,194 \mathrm{~B}$ & $27,125 \mathrm{~A}$ & $35,031 \mathrm{~A}$ & $36,514 \mathrm{~A}$ & $113,869 \mathrm{~A}$ \\
\hline
\end{tabular}

Keterangan: Angka yang diikuti huruf yang sama tidak berbeda nyata setelah diuji lanjut uji duncan beda nyata multiple range test (DMRT) pada taraf $5 \%$

Berdasarkan Hasil pengamatan pada tabel 1diketahui bahwa pemberian bahan organik dapat meningkatkan pertambahan rata-rata tinggi tanaman pada kondisi cekaman kekeringan (60\% KL). Peningkatan kadar bahan organik dapat meningkatkan tinggi tanaman secaara nyata. Pada pemberian $600 \mathrm{~g}$ bahan organik/polybang ternyata meningkatkan 
pertambahan tinggi tanaman tertinggi. Hal yang sama juga diperoleh dari pemberian mikoriza, pemberian mikoriza dapat meningkatkan pertambahan rata-rata tinggi tanaman. dimaan pertambahan tanaman tertinggi diperoleh pada perlakuan M3

\section{Pertambahan Diameter Batang (mm)}

Tabel 2. Jumlah rata-rata pertambahan diameter bibit karet pada 23 MST pada cekaman kekeringan

\begin{tabular}{cccccc}
\hline \multirow{2}{*}{ MIKORIZA } & \multicolumn{5}{c}{ BAHAN ORGANIK } \\
\cline { 2 - 6 } & B0 & B1 & B2 & B3 & RATA-RATA \\
\hline MO & 3,98 & 3,17 & 6,72 & 6,65 & 5,13 \\
M1 & 5,27 & 6,40 & 6,23 & 5,23 & 5,78 \\
M2 & 4,70 & 5,15 & 5,90 & 5,28 & 5,25 \\
M3 & 5,35 & 8,22 & 6,07 & 5,13 & 6,19 \\
\hline TOTAL & 4,82 & 5,75 & 6,23 & 5,57 & 113,869 \\
\hline
\end{tabular}

Berdasarkan hasil pengamatan pada Tabel 2 menunjukkan bahwa pengamatan pemberian bahan organik TKKS sama halnya dengan tinggi tanaman dapat meningkatkan pertambahan rata-rata diameter batang pada cekaman kekeringan $(60 \%$ KL). Rata-rata yang tertinggi diameter tanaman pada perlakuan B2 yaitu 600 g/polybag. Pemberian mikoriza juga dapat meningkatkan pertambahan rata-rata diameter batang pada cekaman kekeringan. Pertambahan diameter terbesar diperoleh dari perlakuan M3 (Glomus). Pemberian bahan organik bersama-sama dengan mikoriza ternyata juga meningkat pertambahan diameter batang pada cekaman kekeringan yaitu pada perlakuan B1M3 (TKKS $300 \mathrm{~g} /$ polybag dengan Mikoriza Glomus + Acaulospora).

Berdasarkan hasil penelitian ini, menujukkan bahwa pemberian bahan organik TKKS dan mikoriza dapat meningkatkan tinggi dan diameter tanaman pada kondisi cekaman kekeringan. Hasil pertambahan tinggi tanaman dan diameter ini dikarenakan peranan bahan organik TKKS yang dapat memperbaiki kualitas tanah baik dari segi fisik, kimia dan biologi tanah. Sesuai dengan pendapat Simamora dan Salundik, (2006) yang menyatakan
(Glomus + Acaulospora). Sedangkan hasil dari interaksi pertambahan tinggi tanaman yang tertinggi diperoleh dari pemberian bahan organik $300 \mathrm{~g} /$ polybag bersamasama glomus + acaulospora. bahwa bahan organik pada umumnya mengandung unsur hara kompleks (makro dan mikro) walaupun dalam jumlah sedikit, selain itu secara fisik bahan organik juga mampu menggemburkan tanah, memperbaiki aerase, meningkatkan penyerapan dan daya simpan air (water holding capacity). Secara kimia bahan organik dapat meningkatkan kapasitas tukar kation (KTK), meningkatkan ketersediaan unsur hara. Secara biologi bahan organik sebagai sumber energi bagi mikroba.

Peningkatan jumlah rata-rata tinggi tanaman dan diameter ini juga disebabkan oleh peranan Pemberian bahan organik TKKS yang dapat memudahkan penyerapan nitrogen oleh tanaman, yakni nitrat dan ammonium. Kedua unsur ini mempercepat pembentukan hijau daun (klorofil) untuk proses fotosintesis guna mempercepat pertumbuhan vegetatif (tinggi tanaman, diameter batang). Hal ini sesuai dengan pernyataan Damanik et al. (2011) yang menyatakan bahwa unsur nitrogen meningkatkan bagian protoplasma sehingga menimbulkan beberapa akibat antara lain terjadi peningkatan ukuran sel daun dan batang. Unsur $\mathrm{N}$ adalah penyusun utama biomassa tanaman muda. 
Pengaruh Pemberian mikoriza sama halnya dengan pemberian bahan organik dapat meningkatkan jumlah rata-rata tinggi tanaman dan diameter batang pada kondisi kekurangan air $(60 \% \mathrm{KL})$ namun pada perlakuan M2 (Acaulospora) justru lebih kecil daripada kontrol hal ini disebabkan bibit karet pada perlakuan M2 mengalami kekerdilan karena M2 tidak efektif dalam menginfeksi akar akibat terjadinya persaingan unsur hara dengan tanaman. Namun pada perlakuan M1 dan M3 dapat Meningkatkan jumlah rata-rata tinggi tanaman. Pertambahan tinggi tanaman dan diameter batang tertinggi Pada perlakuan M3 (Glomus + Acaulospora) disebabkan antar mikoriza saling membantu dalam menginfeksi akar.

Pengaruh mikoriza dalam meningkatkan pertumbuhan tanaman disebabkan karena Mikoriza dapat menyediakan unsur hara terutama $\mathrm{P}$ melalui enzim fosfatase dan juga hifa yang dihasilkan mikoriza yang dapat meningkatkan serapan hara. Sesuai pernyataan lambers et al, (1998) bahwa dalam aktivitasnya mikoriza akan mengeluarkan enzim fosfatase dimana enzim tersebut mampu melarutkan $\mathrm{P}$ yang terfiksasi, sehingga $\mathrm{P}$ yang tersedia ditanah akan meningkat. Asam fosfatase yang terdapat pada hifa mikoriza yang sedang aktif menimbulkan aktivitas fosfatase pada permukaan akar yang menyebabkan $\mathrm{P}$ inorganik dibebaskan dari sumber $P$ organik tanah pada daerah dekat permukaan sel sehingga dapat diserap melalui mekanisme penyerapan hara (Bolan, 1991).

Pemberian TKKS bersama-sama dengan Mikoriza dapat meningkatkan ratarata tinggi tanaman dan diameter batang pada cekaman kekeringan. Tinggi tanaman dan diameter tertinggi ditunjukkan pada perlakuan BIM3 (TKKS $300 \mathrm{~g}+$ Acaulospora+Glomus). Peningkatan ratarata tinggi tanaman dan diameter ini disebabkan peranan Bahan organik TKKS sebagai sumber energi awal untuk perkembangan mikroba dan dapat meningkatkan keefektifan mikoriza melalui peningkatan serapa unsur hara dan air selanjutnya cendawan mikoriza berkembang dan menginfeksi akar untuk membantu serapan hara oleh akar bagi pertumbuhan tanaman melalui hifa. Menurut TIAN et al., (1997) Bahan organik juga berperan sebagai sumber energi dan makanan mikroba tanah sehingga dapat meningkatkan aktivitas mikroba tersebut dalam penyediaan hara tanaman. Jadi, penambahan bahan organik pada bahan pembawa mikoriza, di samping sebagai sumber hara tanaman, sekaligus sebagai sumber energi bagi mikroba.

Interaksi pemberian TKKS dengan Mikoriza meningkatkan diameter batang tertinggi yaitu 8,225 terdapat pada perlakuan B1M3 (300 g/polybag dengan glomus + acaulospora). Hasil yang sama juga dibuktikan dari hasil penelitian Kurniawan et all., (2014) bahwa Pemberian kompos tandan kosong kelapa sawit (TKKS) dengan dosis $300 \mathrm{~g} / \mathrm{tanaman}$ memberikan hasil rataan diameter batang tanaman jagung tertinggi yaitu 18,41 mm. Dari hasil penelitian ini diketahui bahwa dosis TKKS $300 \mathrm{~g} /$ polybag efektif dalam menyuplai unsur hara jika diberikan bersama-sama dengan Mikoriza. Hal ini disebabkan karena bahan organik TKKS memiliki kandungan kalium yang tinggi, memperkaya unsur hara yang ada di dalam tanah. Hal ini sesuai dengan pernyataan Wardani (2012) yang menyatakan bahwa keunggulan kompos TKKS meliputi kandungan kalium yang tinggi, memperkaya unsur hara yang ada di dalam tanah.

\section{SIMPULAN}

Pada kondisi cekaman kekeringan Pemberian bahan organik meningkatkan pertambahan tinggi dan diameter batang bibit tanaman karet pada perlakuan B2 (TKKS $600 \mathrm{~g}$ )

Pada kondisi cekaman kekeringan Pemberian mikoriza meningkatkan pertambahan tinggi tanaman dan 
pertambahan diameter. Perlakuan tertinggi diperoleh perlakuan M3 (Glomus + Acaulospora).

Pada kondisi cekaman kekeringan pemberian antara bahan organik TKKS dan mikoriza meningkatkan diameter dan tinggi tanaman yaitu pada perlakuan B1M3 ( TKKS 300 g dengan Mikoriza Glomus + Acaulospora)

\section{SARAN}

Perlunya hasil penelitian ini dilanjutkan pada kondisi daerah yang mengalami cekaman kekeringan. Untuk menguji keefektifan bahan organik TKKS dan mikoriza.

\section{DAFTAR PUSTAKA}

Abdullah S, Y. Musa, dan Feranita H. 2005. Perbanyakan Cendawan Mikoriza Arbuskula (CMA) Pada Berbagai Varietas Jagung (Zea mays L) Dan Pemanfaatannya Pada Dua Varietas Tebu (Saccharum officinarum L). Jurnal Sains Dan Teknologi. Vol 5 (1):12-20.

Ai, N.S, dan Torey, P. 2013. Karakter Morfologi Akar Sebagai Indikator Kekurangan Air Pada Tanaman (Root morphological characters as water-deficit indicators in plants) JURNAL

BIOSLOGOS, FEBRUARI 2013, VOL. 3 NOMOR 1

Anggraini, E. 2009. Pemanfaatan Mikoriza Untuk Meningkatkan Pertumbuhan Dan Produksi Tembakau Deli (Nicotiana Tabacum L.) Pada Kondisi Cekaman Kekeringan. Tesis. Universitas Sumatera Utara. Medan

Badan Pusat Statistik. 2009. EksporImpor Karet. Badan Pusat Statistik. Jakarta

Bertham, YH,C.kusuma, Y. Setiadi, I. Mansur dan D. Sopandie. 2006. Pemanfaatan CMA dan brandyrhizobium untuk meningkatkan produktifitas kedelai pada sistem agroforestri berbasis kayu bawang(Scorodocarpus berneensis) pada ultisol. Akta Agrosia 9(1): 36-41

Brundret, M., N. Bougher, B. Dell, T. grove, and N. Malajczuk. 1996. Working With Mycorhizas In Forestry And Agriculture. ACIAR Monograf 32. 374+ xp.

Chairani Hanum, Wahyu Q Mugnisjah, Sdirman Yhya, Didi Sopandi, Komaruddin Idris, Dan Asmarlaili Sahar. 2007. Pertumbuhan Akar Kedelai Pada Cekaman Aluminium, Kekeringan Dan Cekaman Ganda Aluminium Dan Kekeringan. Agritop, 26(1):13-18

Cristine, Y. 2014. Pengaruh Berbagai Kadar Air Tanah Pada Efektivitas Mikoriza Arbuskular Terhadap Bibit Karet (Hevea Brasiliensis) Dirumah Kasa. Skripsi. Universitas Sumatera Utara

Damanik, S .2012. Pengembangan Karet (Havea brasiliensis Muell.arg) ) Berkelanjutan di Indonesia. Perspektif Vol. 11 No. 1 /Juni 2012. Hlm 91 - 102

Damardono, 1996. Pengaruh Elevasi Terhadap Produktivitas Karet Dan Klasifikasinya. J. Penelitian Karet , 14(1)

Dinas Perkebunan Propinsi Jambi. 1993. Vedemecum Karet. Jambi $280 \mathrm{Hal}$

[Ditjenbun]. Direktorat Jenderal Perkebunan. 2013. Produksi dan produktivitas karet di Indonesia. http/:www.dirjenbun.go.id, di akses 7 Januari 2014.

Delvian. 2003. Keanekaragaman Cendawan Mikoriza Arbuskula (CMA) di Hutan Pantai dan Potensi Pemanfaatannya: Studi Kasus di Hutan Cagar Alam Leuweung Sancang Kabupaten Garut, Jawa Barat. Disertasi Doktor. Institut Pertanian Bogor, Bogor

Effendy, Y. 2008. Kajian Resistensi Beberapa Varietas Padi Gogo (oryza sativa 1.) Terhadap Cekaman 
Kekeringan. Tesis. Universitas Sebelas Maret. Surakarta

Fisher R.A and turner, N.C. 1978. Plant Productivity In The Arid And Semi Arid Zones. An.Rev.Plant Phys. 29 : 277-317

Foth, H.D. 1984. Dasar-Dasar Ilmu Tanah. Terjemahan Purbayanti, E.D. Dwi R. L. Rayahayuning T. Gajah Mada University Press. Yogyakarta.

Gardner, F.P.;Pearce, R.B and mithcell, R.L.1991. Fisiologi Tanaman Budidaya. Terjemahan Herawati Susilo. UI Press. Jakarta. Hal 98, 350

Hapsoh. 2003. Kompatibilitas MVA dan Beberapa Genotipe Kedelai Pada Berbagai Tingkat Cekaman Kekeringan Tanah Ultisol:Tanggap Morfosiologi dan Hasil. Disertasi. Sekolah Pascasarjana Institut Pertanian Bogor, Bogor

Heddy, 1987. Biologi Pertanian. CV Rajawali: Jakarta

Istianto, 1993. Potensi Dan Kompatibilitas Mikoriza Vesikular Arbuskular (Mva) Dengan Bibit Tanaman Karet (Hevea brasiliensis MUELL Arg.) Klon Pb 260. Tesis. Universitas Sumatera Utara

Kabirun, S. 2002. Tanggapan Padi Gogo Terhadap Inokulasi Jamur Mikoriza Arbuskula Dan Pemupukan Fosfat Di Entisol. Jurnal Ilmu Tanah Dan Lingkungan Vol. 3(2):49-56

Karyudi. 2001. Osmoregulasi Tanaman Karet (Hevea brasiliensis Mull.Arg) Sebagai Respon Terhadap Cekaman Air.I.Variasi Diantara Klon Anjuran Harapan Dan Plasma Nutfah. Jurnal Penelitian Karet, 19(1-3), 1-17

Karyudi, Siagian, N., dan Hanafiah, A., 2004. Osmoregulasi Tanaman Karet (Hevea brasiliensis) Sebagai Respon Terhadap Cekaman Air.II. Hubungan Antara Kapasitas
Osmoregulasi Dengan Pertumbuhan Tanaman Dan Status Hara Daun. Jurnal penelitian Karet 22(1), 69-80

Kormanik PP and McGraw Ac. 1982. Quantification of Vesikuler Arbuskuler Mycorrhizae in Plant Roots. In: Schenk NC (ed.), Method and Principles of Mychorhizal Research. The American Phytopatological Society, St paul. 22,37-45

Levitt, J. 1980. Responses of Plants to Environmental Stresses. Vol. II : Water, Radiation, Salt, and Other Stresses. Academic Press. New York. 607 p

Lugtenberg,B.J.J and Lev V Kravchenko.1999. Tomato Seed And RootExudate Sugars:Composition,Utilization By PseudomonasBiocontrol Strains And Role InRhizosphere Colonization.Enviromental Microbiology. Vol 1(5). Hal 439446.

Lukiwati, D. R. 2007. Peningkatan produksi bahan kering dan kecernaan Pueraria phaseoloides dan Centrosema pubescensdengan batuan fosfat dan inokulasi Mikoriza arbuskular. Jurnal IlmuIlmu Pertanian Indonesia 9: 1-5.

Mapengau. 2006. Pengaruh Cekaman Air Terhadap Pertumbuhan Dan Hasil Tanaman Kedelai. Jurnal Ilmiah Pertanian Kultura vol. 41 no. 1

Mawardi dan Djazuli. 2006. Pemanfaatan Pupuk Hayati Mikoriza Untuk Meningkatkan Toleransi Kekeringan Tanaman Nilam. Jurnal Littri 12(1), 38-43

Mayerni, R dan D. Hervani. 2008. Pengaruh Jamur Mikoriza Arbuskula Terhadap Pertumbuhan Tanaman Selasih (ocimum sanctum. L). Jurnal Akta Agrosia vol.11(1):7-12

Nasahi, Ceppy. 2010. Peran Mikroba Dalam Pertanian Organik. Makalah 
Jurusan Hama Dan Penyakit Tumbuhan Fakultas Pertanian Universitas Padjadjaran Bandung. Bandung

Nazaruddin dan Paimin, 1992. Budidaya dan Pengolahan Karet. Strategi Tahun 2000. Penebar Swadaya, Jakarta.

Nurhayati. 2007. Seleksi Mekanisme Toleransi Tanaman Tembakau (Nicotiana Tabacum .L) Terhadap Kekeringan. Disertasi. Universitas Sumatera Utara. Medan

Neliyati. 2010. Pertumbuhan Batang Bawah Bibit Karet (Hevea brasiliensis Mull.Arg) Dengan Pemberian Mikoriza Arbuskula Pada Beberapa Kondisi Air Polybag. Jurnal Karet, 14(2)

Pangaribuan, Y. 2001. Studi Karakter Morfofisiologi Tanaman Kelapa Sawit (elaeis guineensis jaq) di Pembibitan Terhadap Cekaman Kekeringan. Tesis. Program Pascasarjana, Istitut Pertanian Bogor. Bogor

Prasetyo. B.H dan Suriadikarta D.A, 2006. Karakteristik, Potensi Dan Teknologi Pengelolaan Tanah Ultisol Untuk Pengembangan Pertanian Lahan Kering Di Indonesia. Jurnal Litbang Pertanian, 25(2), 2006.

Prayudyaningsih, 2014. Pertumbuhan Semai Alstonia Scholaris, Acacia Auriculiformis Dan Muntingia Calabura Yang Diinokulasi Fungi Mikoriza Arbuskula Pada Media Tanah Bekas Tambang Kapur. Jurnal Penelitian Kehutanan Wallace Vol. 3 no.1, April 2014 : $13-23$

Purwati, 2013. Pertumbuhan Bibit Karet (Hevea Brasiliensis) Asal Okulasi Pada Pemberian Bokashi Dan Pupuk Organik Cair Bintang Kuda Laut. Jurnal AGRIFOR Volume XII Nomor 1.

Salisbury, F.B., dan C.W. Ross. 1995. Fisiologi tumbuhan. Jilid 1
Terjemahan Diah R. Lukman dan Sumaryo. ITB, Bandung.

Santoso, E., Indry., A.W. Gunawan., K.Tawaraya. \&M. Turjaman. 2007.Early colonization of arbuscularmycorrhizal fungi in tree producinggaharuAquilaria

microcarpaseedlings. Dalam

Prosiding KongresNasional Mikoriza II. ' PercepatanSosialisasi Teknologi Mikoriza untukMendukung Revitalisasi Kehutanan,Pertanian dan Perkebunan". Bogor.17-21 Juli 2007.

Sianturi, H. S. D., 2001. Budidaya Tanaman Karet. USU Press. Medan

Subiksa, I.G.M. 2002. Pemanfatan Mikoriza Untuk Penanggulangan Lahan Kritis. Makalah Falsafah Sains Program PascaSarjana Institut Pertanian Bogor. Bogor

Sugiyanto, Y. 1987. Sifat-Sifat Fisik Tanah Penentu Agihan Akar Tanaman Karet Dewasa Di Tanah Podsolik Merah Kuning Sumatera Utara. Tesis. Universitas Gadjah Mada. Yogyakarta

Sutoro, N. Dewi dan M. Setyowati. 2008. Hubungan Sifat Morfofisiologis Tanaman dengan Hasil Kedelai. Jurnal Penelitian Tanaman Pangan Vol. 27, No. 3, Tahun 2008. Hal. 185-190

Setiawan,A. I., 2000. Penghijauan Dengan Tanaman Potensial. Kanisius, Yogyakarta

Setyamidjaja, D., 1993. Karet Budidaya Dan Pengolahan. Kanisius, Yogyakarta.

Siagian, N., 2005. Klon-Klon Anjuran Tanaman Karet. Balai Penelitian Karet Sungei Putih. Tanjung Morawa

Seta, A.K. 1987. Konservasi Sumber Daya Tanah dan Air. Jakarta:Kalam Mulia

Soekardi, M.,M.W. Retno, dan Hikmatullah. 1993. Inventarisasi 
Dan Karakteristik Lahan AlangAlang. Pusat Penelitian Tanah Dan Agroklimat. Badan Litbang Pertanian

Scholes, M.C., Swift, O.W., Heal, P.A. Sanchez, JSI., Ingram and R. Dudal, 1994. Soil Fertility research in response to demand for sustainability. In The biological managemant of tropical soil fertility(Eds Woomer, Pl. and Swift, MJ.) John Wiley \& Sons. New York.

Tian, G.,L BRUSSARD, B T., KANG and M. J. SWIFT.1997. Soil faunamediated decomposition of plant residues under contrined environtmental and residue quality condition. In Driven by Nature plant litter quality and decompotion, departmen of Biological Sciences. (Eds Cadish, G. and GILLER, K.E.), pp 125134. Wey college, University of London, UK

Toruan, Mathius N, J,. Santoso, K,. Dediwan \& E. Tresnawati,. 2007. Pemanfaatan Bioteknologi Untuk Pengembangan Kina Di Indonesia. Makalah Lokakarya Kina Nasional. Bandung.1-18.

Thomas, 1996. Estimasi Potensi Pertumbuhan Tanaman Karet Dengan Menggunakan Indeks Kelegasan Tanah Pada Beberapa Lokasi Di Nusa Tenggara Barat. J. Penelitian Karet, 14(1).

Trisilawati, O dan C. Firman. 2004. Pengaruh Cendawan Mikoriza Arbuskula Terhadap Pertumbuhan Bibit Panili (Vanilla planifolia Andrews). Buletin TRO. Vol.XV (1):19-24

Yusnaini, 2009. Keberadaan Mikoriza Vesikular Arbuskular Pada Pertanaman Jagung Yang Diberi Pupuk Organik dan Inorganik Jangka Panjang. J. Tanah Trop., Vol. 14, No.3, 2009: 253-260 